\title{
CHÍNH SÁCH CỦA THỰC DÂN PHÁP ĐỐI VỚI CÁC DÂN TộC THIỂU SỐ Ở TÂY NGUYÊN
}

\author{
Nguyễn Văn Bắc ${ }^{\mathrm{a}^{*}}$ \\ ${ }^{a}$ Khoa Lịch sủ, Truoòng Đại học Đà Lạt, Lâm Đồng, Việt Nam \\ "Tác giả liên hệ: Email: bacnv@dlu.edu.vn \\ Lịch sử bài báo \\ Nhận ngày 22 tháng 11 năm 2019 \\ Chỉnh sửa ngày 18 tháng 12 năm 2019 | Chấp nhận đăng ngày 15 tháng 01 năm 2020
}

\section{Tóm tắt}

Sau khi về co bản dập tắt phong trào Cần Vuơng, tù cuối thế kỷ XIX, người Pháp bắt đầu tiến hành điều tra tất cá các khu vực địa lý trên toàn lãnh thổ Việt Nam để làm cơ sở cho việc xây dưng chính sách cai trị phù hợp với tùng địa bàn. Vị trí chiến luợc về địa chính trị-địa quân sư, nguồn tài nguyên phong phú, và sự đa dạng về tộc ngườ ở Tây Nguyên đã tạo ra sức hút mạnh mẽ không chỉ đối với nhà cầm quyền thưc dân mà còn đối với giới học giả thuộc nhiều lĩnh vục học thuật khác nhau. Cho đến nay, mặc dù đã có nhiều học giả quan tâm đến lịch sử vùng đất Tây Nguyên thời thuộc địa (đặc biệt là cụm các công trình về lịch sủ Đảng bộ và Du địa chí các địa phuoong) nhưng các nghiên cưu này chủ yếu tập trung mô tả chính sách bóc lột của người Pháp và lịch sủ đấu tranh cách mạng của các dân tộc thiểu số duới sự lãnh đạo của Đảng. Trên cơ sở phân tích hệ thống văn bản pháp quy của Toàn quyền Đông Duơng, Quốc truởng Bảo Đại, và tổng hợp nhũ̃ng nghiên cứu liên quan, tác giả bài viết này hy vọng sẽ góp phần làm rõ thêm về quá trình thiết lập hệ thống chính quyền, tổ chức sắp xếp các đơn vị hành chính cấp tỉnh, và chính sách dân tộc của thực dân Pháp đối với các dân tộc thiểu số ở Tây Nguyên.

Từ khóa: Chính sách cai trị; Dân tộc thiểu số; Đơn vị hành chính cấp tỉnh; Tây Nguyên.

DOI: http://dx.doi.org/10.37569/DalatUniversity.10.1.625(2020)

Loại bài báo: Bài báo nghiên cứu gốc có bình duyệt

Bản quyền @ 2020 (Các) Tác giả.

Cấp phép: Bài báo này được cấp phép theo CC BY-NC 4.0 


\title{
THE FRENCH POLICY TOWARDS ETHNIC MINORITIES IN THE CENTRAL HIGHLANDS
}

\author{
Nguyen Van Bac ${ }^{\mathrm{a}^{*}}$ \\ ${ }^{a}$ The Faculty of History, Dalat University, Lamdong, Vietnam \\ *Corresponding author: Email: bacnv@dlu.edu.vn \\ Article history \\ Received: November $22^{\text {nd }}, 2019$ \\ Received in revised form: December $18^{\text {th }}, 2019 \mid$ Accepted: January $15^{\text {th }}, 2020$
}

\begin{abstract}
After bloodily suppressing the Cần Vuong movement in the late nineteenth century, the French started conducting surveys of all geographic areas throughout the territory of Vietnam to provide bases for developing appropriate policies for each locality. The Central Highlands held special attraction, not only to colonial rulers, but also to scholars of various academic areas because of its important strategic location, abundant resources, and ethnic diversity. While substantial attention has been given to the history of the Central Highlands during the colonial period (for example, the group of works on the history of the Provincial Communist Party Committee and unification records of each province), limited attention has been bestowed upon the process of setting up the governmental system, arranging provincial administrative units, and the French policies for ethnic minorities. By examining legal documents issued by the Governor-General of Indochina and the Chief of State Bảo Đai, and by reviewing related studies, the author hopes to contribute some new insights about the points mentioned above.
\end{abstract}

Keywords: Central Highlands; Domination strategy; Ethnic minorities; Provincial administrative unit.

DOI: http://dx.doi.org/10.37569/DalatUniversity.10.1.625(2020)

Article type: (peer-reviewed) Full-length research article

Copyright () 2020 The author(s).

Licensing: This article is licensed under a CC BY-NC 4.0 


\section{DÃ̃N NHậP}

Từ thế kỷ XVII, các nhà truyền giáo phương Tây đã quan tâm đến vùng đất Tây Nguyên, đặc biệt là sau khi Hội Thừa sai Paris (Missions Étrangères de Paris-MEP) ra đời vào năm 1658. Nhiều nguồn tài liệu chỉ ra rằng sự xuất hiện của các giáo sĩ Công giáo đã góp phần quan trọng làm thay đổi mối quan hệ quyền lực giữa các nhóm trong cộng đồng người Thượng (Cửu \& Toan, 1974; Maitre, 2008). Cùng với các nhà truyền giáo, những khám phá của các nhà thám hiểm người Pháp dần vén bức màn bí ẩn về vùng núi phía Nam Đông Dương.

Để chuẩn bị cho công cuộc "bình định" khu vực này, năm 1880, Thống đốc Charles Marie Le Myre de Vilers ${ }^{1}$ đã đề ra một số chính sách đầu tiên dành cho các dân tộc thiểu số ở Tây Nguyên. Do vấp phải sự phản đối mạnh mẽ của các nhóm cư dân tại chỗ, mặt khác, cũng là để tối ưu hóa lợi ích của "mẫu quốc", chính sách cai trị của thực dân Pháp sau đó đã nhiều lần được điều chỉnh. Đáng chú ý nhất là những sửa đổi được thực hiện bởi Pierre Marie Antoine Pasquier vào năm 1923 và Georges Thierry d'Argenlieu sau Cách mạng tháng Tám năm 1945.

Cho đến nay, mặc dù đã có nhiều chuyên khảo thuộc các lĩnh vực địa lý, lịch sử cư trú, và các đặc điểm về sinh hoạt kinh tế, xã hội, và văn hóa truyền thống của các tộc người thiểu số ở Tây Nguyên được công bố, nhưng quá trình thiết lập bộ máy hành chính thuộc địa và chính sách dân tộc của chính quyền thực dân Pháp ở vùng đất này vẫn chưa được nghiên cứu một cách kỹ lưỡng. Bằng việc khảo cứu nguồn tài liệu lưu trữ, cũng như tổng hợp kết quả nghiên cứu của những học giả đi trước, tác giả bài viết hy vọng sẽ góp thêm một vài nhận thức mới về quá trình tổ chức bộ máy cai trị, sắp đặt các đơn vị hành chính cấp tỉnh, cũng như chính sách dân tộc mà chính quyền thực dân đã áp dụng ở vùng đất có vị trí chiến lược quan trọng này.

\section{CHÍNH SÁCH CỦA THỰC DÂN PHÁP ĐỐI VỚI CÁC DÂN TộC THIỂU SỐ Ở TÂY NGUYÊN}

\subsection{Những liên hệ đầu tiên giữa người Pháp và cộng đồng người Thượng}

\subsubsection{Sự hiện diện của các giáo sĩ châu Âu ở vùng ngườ Thượng}

Vào cuối thế kỷ XVI và đầu thế kỷ XVII, giới thương nhân từ các nước phương Tây như Bồ Đào Nha, Anh, và Pháp và châu Á như Nhật Bản và Trung Quốc bắt đầu thiết lập quan hệ thương mại với Đại Việt để trao đổi hàng hóa và trang thiết bị quân sự (Li, 1998, tr. 41-45). Cũng trong khoảng thời gian đó, Ki-tô giáo đã phát động các hoạt động truyền giáo quy mô lớn trên khắp thế giới, bao gồm khu vực Viễn Đông. Theo sách Khâm định Việt sử thông giám cuơng muc, bộ sử ký được biên soạn dưới triều vua Tự Đức, thì từ năm 1533, Ki-tô giáo lần đầu tiên được truyền bá một cách "lén lút" tại các làng Ninh Cường và Quần Anh, huyện Nam Chân, và làng Trà Lũ, huyện Giao

${ }^{1}$ Charles Marie Le Myre de Vilers (1833 - 1918) là một chính khách và nhà ngoại giao người Pháp. Ông được bổ nhiệm là Thống đốc dân sự đầu tiên của Nam Kỳ trong giai đoạn 1879 - 1882. 
Thủy (Nam Định) bởi một nhà truyền giáo phương Tây tên là I-ni-khu (Quốc sử quán triều Nguyễn, 2001, tr. 720). Mặc dù phải đương đầu với nhiều khó khăn và thử thách ${ }^{2}$, số lượng tín đồ của tôn giáo này vẫn tăng liên tục, các giáo phận Đàng Trong và Đàng Ngoài lần lượt được thành lập vào những năm đầu thế kỷ XVII, đặc biệt, kể từ khi Hội Thừa sai Paris ra đời vào năm 1658 và được Giáo hoàng Alexander VII thừa nhận vào năm 1664 (Nguyễn, 1959).

Năm 1802, Nguyễn Phúc Ánh (1802-1820) lên ngôi, trở thành vị Hoàng đế đầu tiên của triều Nguyễn. Để bày tỏ lòng biết ơn của mình đối với Giám mục Pigneau de Behaine $^{3}$ (tên Việt là Bá Đa Lộc hay Bá Đa Lộc Bỉ Nhu), vua Gia Long tỏ ra khá cởi mở với Công giáo, cho phép tôn giáo này được truyền bá rộng rãi trong đất nước của ông. Tuy nhiên, từ thời vua Minh Mạng (1820-1840) trở đi, do bị nhìn nhận như là một mối nguy cơ đối với chủ quyền và nền văn hóa truyền thống của dân tộc nên Công giáo bị cấm đoán nghiêm ngặt. Các giáo sĩ thừa sai, do đó, đã phải di chuyển đến Tây Nguyên để tị nạn và cũng là để tìm cách truyền bá đức tin Thiên Chúa vào các cộng đồng người thiểu số. Sự xâm nhập của người Pháp và sau đó là người Việt vào địa bàn cư trú lâu đời của người Thượng là tiền đề cho sự hợp tác hoặc chống đối của cộng đồng này trong các thời kỳ sau đó.

Trên thực tế, từ thế kỷ XVII, rất lâu trước khi các Hoàng đế triều Nguyễn ban hành các đạo dụ cấm đạo, các nhà truyền giáo phương Tây đã biết đến cộng đồng người Thượng. Trong một hồi ký được viết vào năm 1621, giáo sĩ dòng Tên, Christoforo Borri, gọi chung các nhóm thiểu số cư ngụ ở phía bắc Đàng Trong là Kemoy (Kẻ Mọi) (Borri, 2014). Các tài liệu về lịch sử truyền giáo tại Việt Nam tiết lộ rằng Cha Marini Romain lần đầu tiên đề cập về Vua Nước và Vua Lửa vào năm 1646. Cha Alexandre de Rhodes cũng nhắc đến Quốc gia Rumoi (Rú Mọi) hay "Khu rừng của những kẻ man rợ" nằm giữa Lào và An Nam năm 1651. Năm 1790, và Cha João de Loureira đã xuất bản cuốn sách De nigris Moi et Champanensibus (tạm dịch là Về người da sẫm màu và nguời Champa) ở Lisbon... Cho đến đầu thế kỷ XIX, mặc dù kiến thức của các nhà truyền giáo về vùng đất Tây Nguyên ngày càng tăng nhưng hiệu quả của hoạt động mục vụ ở đây vẫn còn khá khiêm tốn (Hồng, Cadière, \& Nguyễn, 1944; Maitre, 2008; Nguyễn, 1959; \& Salemink, 2002).

Trong giai đoạn vua Tự Đức trị vì (1848-1883), khi cuộc đàn áp tôn giáo trở nên dữ dội ở vùng đồng bằng, các giáo sĩ đã nỗ lực tìm đường đến các vùng cao nguyên để tìm lối thoát cho sứ mệnh mở rộng nước Chúa ${ }^{4}$. Tại Nam Kỳ, vào năm 1857 , Cha Lefèbvre đã phái một người thân tín đến không gian sinh tồn của người S'tiêng (phía tây

\footnotetext{
${ }^{2}$ Chẳng hạn như sự khác biệt về ngôn ngữ, sự cảnh giác của chính quyền phong kiến Đại Việt, và sự phản kháng mạnh mẽ từ các tín ngưỡng dân gian bản địa cũng như các tôn giáo có nguồn gốc từ Ân Độ và Trung Quốc đã được truyền bá ở đất nước này trong nhiều thế kỷ.

${ }^{3}$ Pigneau de Behaine là một nhà truyền giáo người Pháp hỗ trợ Nguyễn Ánh tích cực giành lại quyền lực từ Tây Sơn vào cuối thế kỷ XVIII (Phan, 1961, tr. 55-73).

${ }^{4}$ Năm 1854, chính quyền phong kiến ở Bình Định đã ra lệnh cho các quan lại hành chính và tướng lĩnh quân sự ở Tây Nguyên bắt giữ tất cả các giáo sĩ. Tuy nhiên, không ai trong số người Thượng thực hiện mệnh lệnh, thậm chí họ còn cố tình đánh lạc hướng binh lính triều đình. Kết quả là, những người lính được gửi đến đã phải bỏ cuộc và rút lui sau khi bị bỏ đói trong rừng (Cửu \& Toan, 1974, tr. 102).
} 
bắc Gia Định) để tìm chốn nương thân. Năm 1861, linh mục Azémar thành lập tu viện Brơlam ở Bình Long (Hồng \& ctg., 1944; Nguyễn, 1959).

Dù đã sớm biết đến Tây Nguyên nhưng mãi đến giữa thế kỷ XIX, các hoạt động mục vụ trong cộng đồng người Thượng mới được người Pháp đẩy mạnh. Năm 1848, giám mục Giáo phận Đông Đàng Trong (Quy Nhơn), Etienne Théodore Cuénot, phái Nguyễn Do, một tín đồ người Việt, thâm nhập vào lãnh thổ của người Jarai ở An Khê. Hai năm sau, khi đã ổn định chỗ đứng chân, Nguyễn Do dẫn bốn nhà truyền giáo người Pháp là Combes, Fontaine, Dourisboure, và Besombes đến nơi ở của người $\mathrm{Ba} \mathrm{Na}$, Rengao, và Sédang (Xơ-đăng). Khi trở về đồng bằng, các linh mục vừa nêu đã vẽ bản đồ địa hình và ghi chép chi tiết về mối liên hệ giữa phong tục của các nhóm dân tộc Tây Nguyên. Hai năm sau khi thành lập, năm 1851, Hội truyền giáo Kon Tum đã phát triển cơ sở vững chắc tại bốn ngôi làng gần ngã ba sông Đắk Bla và Poko (Cửu \& Toan, 1974, tr. 100-101).

Theo mô tả của các nhà truyền giáo, vào giữa thế kỷ XIX, các tộc người Sédang, Jarai, và $\mathrm{S}$ 'tiêng "rất hung dữ", thường bắt người Rengao $\mathrm{Ba} \mathrm{Na}$, Sédang Halang, và M'nông Bhiet đem bán sang Xiêm (Siam-Thái Lan) và Lào làm nô lệ (Maitre, 2008, tr. 245). Vào năm 1862, nhân sự kiện bệnh đậu mùa hoành hành tại Tây Nguyên, các pháp sư người Thượng kêt luận rẳng Giáo hội là nguyên nhân của sự phẫn nộ và trừng phạt của Jang (các vị thần linh). Với niềm tin đó, các thủ lĩnh người Jarai và Sédang đã kêu gọi người dân của họ đốt cháy các ngôi làng Công giáo $\mathrm{Ba} \mathrm{Na}$. Trước những mối đe dọa này, các nhà truyền giáo Pháp đã giúp người $\mathrm{Ba} \mathrm{Na}$ thành lập một lực lượng tự vệ vũ trang gồm 1,200 người vào năm 1883 (Nguyen, 2019, tr. 93).

Có thể nói, sự xuất hiện của các giáo sĩ Công giáo đã làm thay đổi mối quan hệ quyền lực giữa các dân tộc thiểu số ở Tây Nguyên. Và, sứ mệnh Ki-tô giáo trong vùng người Thượng đưa đến một tác động kép: Một mặt là góp phần hiện đại hóa; Mặt khác, quan trọng hơn, là tìm cách kiểm soát địa bàn này để mở rộng đức tin Thiên chúa. Các nhà truyền giáo người Âu và người Việt đã dạy các kỹ thuật thâm canh và chăn nuôi gia súc cho người $\mathrm{Ba} \mathrm{Na}$ theo Công giáo. Quan trọng hơn, các giáo sĩ còn giúp huấn luyện và trang bị để tín đồ $\mathrm{Ba} \mathrm{Na}$ của họ có thể tự vệ hiệu quả trước các cuộc tấn công của người Jarai và Sédang, góp phần chấm dứt hoạt động buôn bán nô lệ ở Tây Nguyên (Cửu \& Toan, 1974, tr. 103).

\subsubsection{Nhũng chuyến thám hiểm đầu tiên của người Pháp ở Tây Nguyên}

Cùng với các nhà truyền giáo, những khám phá của các nhà thám hiểm người Pháp dần hé lộ rất nhiều bí ẩn ở vùng núi phía nam Đông Dương, nơi trước đó vốn được coi là "rừng thiên nước độc". Trong những chuyến khảo sát, các nhà thám hiểm cũng phát hiện nguồn tài nguyên thiên nhiên phong phú và đang bị bỏ quên ở Tây Nguyên. Báo cáo của họ là một trong những căn cứ quan trọng để Toàn quyền Đông Dương (Gouverneur général de l'Indochine française) Paul Doumer xây dựng kế hoạch cho chương trình khai thác thuộc địa vào cuối thế kỷ XIX, cũng như các chương trình kinh tế xã hội khác được triển khai ở vùng người Thượng trong những giai đoạn sau. 
Sau khi Pháp chiếm Nam Kỳ, Thống đốc Le Myre de Vilers đã ra lệnh cho trung úy Amédée Gautier điều tra ranh giới phía đông bắc của phần lãnh thổ này. Năm 1881, Gautier khởi hành từ thác Trị An, đi ngược sông Đồng Nai. Sau một hành trình dài, theo hướng dẫn của người dẫn đường, viên trung úy dừng lại để khảo sát tại vùng người S’tiêng ở Bù Đăng, lưu vực sông Da Glun (một nhánh của sông Bé) (Cửu \& Toan, 1974, tr. 124-128).

Để chuẩn bị và chủ động loại bỏ những rắc rối do Xiêm gây ra ở các vùng giáp ranh giữa Việt Nam với Trung Quốc và Việt Nam với Campuchia, Auguste Pavie được giao nhiệm vụ khảo sát các vấn đề về địa chất và quân sự, sau đó, là lập bản đồ Đông Dương. Vào những năm 1890 và 1891, dưới sự lãnh đạo của Pavie, hai nhóm khảo sát có nhiệm vụ điều tra vùng Tây Nguyên đã được thành lập. Đội đầu tiên bao gồm hai đại úy De Malglaive và Tunnelet Faber được phân công điều tra khu vực Sébang-biên. Đội còn lại gồm hai đại úy Cupet và Cogniard, trung úy Dugast, và thanh tra Garnier được giao nhiệm vụ khảo sát khu vực từ Pleiku đến Kon Tum (Cửu \& Toan, 1974).

Tháng 7 năm 1890, bác sĩ Alexandre Yersin đã lên kế hoạch cho một chuyến đi đường bộ từ Nha Trang lên Tây Nguyên, sau đó trở về Sài Gòn. Tuy nhiên, do không tìm được người dẫn đường cho lộ trình dự kiến, ông đến Phan Rí (tỉnh Bình Thuận) và từ đó đi lên Di Linh. Sau khi trở về Nha Trang, vào tháng 4 năm 1892, ông lại tổ chức một chuyến đi khác từ Nha Trang đến Stung Treng (Campuchia). Vào tháng 3 năm 1893, một lần nữa, Bác sĩ Alexandre Yersin đã tổ chức một chuyến thám hiểm từ Nha Trang đến Phan Thiết. Ngày 21 tháng 6 cùng năm, ông đến cao nguyên Langbian và bị thu hút nhiều bởi địa hình, cảnh quan, và khí hậu mang đậm nét Âu châu ở đó. Dựa trên phát hiện này, năm 1899, ông đã khuyên Toàn quyền Doumer chọn Đà Lạt làm trung tâm nghỉ dưỡng cho các sĩ quan quân đội và công chức hành chính Pháp ở miền nam Đông Dương (Cửu \& Toan, 1974).

Năm 1904, thanh tra viên Prosper D'Odend'hal (người trước đó từng tham gia cuộc thám hiểm của Pavie) rời Phan Rang để đến Langbian và Đắk Lắk. Trên đường đi, D'Odend'hal dừng lại tại Cheo Reo để liên lạc với Vua Lửa (Oi Ât) và đã được chào rất nồng nhiệt. Tuy nhiên, do đang bị bệnh, các nhà thám hiểm đã từ chối lời mời uống rượu và ăn thịt gà từ phía chủ nhà. Nghiêm trọng hơn, D'Odend'hal khăng khăng đòi được xem thanh kiếm thiêng mà chỉ duy nhất "nhà vua" mới được nhìn thấy. Những cử chỉ này đã tạo ra sự ngờ vực từ phía chủ nhà. Vụ việc được đẩy đến đỉnh điểm khi Odend'hal gửi một bức thư cho chỉ huy đội quân đồn trú tại Cheo Reo. Cho rằng đó là yêu cầu tiếp viện để đàn áp cộng đồng của mình, Vua Lửa Oi Ất đã ra lệnh cho thuộc hạ giết chết viên thanh tra vào ngày 07 tháng 4 năm 1904 (Dournes, 2013, tr. 32-33).

Cuối cùng, một trong những nhà thám hiểm không thể không đề cập tới là Henri Maitre, người đã khảo sát Buôn Mê Thuột và các cao nguyên xung quanh trong vòng ba năm để viết nên tác phẩm nổi tiếng Rùng người Thương (Les jungles Mọi), công bố lần đầu tại Paris năm 1912. Bên cạnh vai trò của một nhà thám hiểm và nhà văn, Maitre còn là một sĩ quan quân đội (đại úy, đồn trưởng đồn $\mathrm{Bu}$ Méra). Cũng vì vai trò này mà ông bị phục kích và giết chết bởi N'Trang Lơng, một lãnh tụ nghĩa quân nổi tiếng của người 
M'nong vào tháng 8 năm 1914 (Cửu \& Toan, 1974; Đinh, Nguyễn, \& Nguyễn, 2000; Maitre, 2008).

\subsection{Một số điều chỉnh tiêu biểu trong chính sách dân tộc của Pháp ở Tây Nguyên}

\subsubsection{Chính sách dân tộc trong thời kỳ đầu xác lập ảnh hưởng của các nhà thực dân}

Để chuẩn bị cho việc bình định các khu vực miền núi ở Đông Dương, năm 1880 , Thống đốc Le Myre de Vilers đã đề ra chính sách đầu tiên dành cho cộng đồng người Thượng. Gói chính sách này gồm ba nội dung chính là: i) Khảo sát địa hình và phong tục truyền thống tại các khu vực có hoạt động nổi dậy hoặc nơi các nhà thực dân chuẩn bị chiếm đóng; ii) Xây dựng một hoặc nhiều đồn quân sự để gây ảnh hưởng và thiết lập một đại diện hành chính để cai quản mỗi khu vực; \& iii) Tìm những vùng dân chúng dễ hợp tác và sử dụng các biện pháp thân thiện để thu hút họ, tránh sử dụng vũ lực (Cửu \& Toan, 1974, tr. 128-129).

Chính sách này được thực hiện trong giai đoạn 1881 - 1885 nhưng không mang lại nhiều kết quả. Các tộc người “hung hăng” như S'tiêng luôn chiến đấu chống lại sự hiện diện của các nhà thực dân, trong khi những cộng đồng được cho là hiền lành hơn như Mạ thì cố gắng tránh xa họ. Ngoài ra, trong thời kỳ này nhiều cuộc nổi dậy liên tiếp nổ ra trên địa bàn Trường Sơn-Tây Nguyên, vì vậy các nhóm người Thượng thường từ chối hợp tác với người Pháp.

Với lý do Trường Sơn từng là căn cứ kháng chiến Sơn Phòng của quân Khởi nghĩa Cần Vương, người Pháp buộc triều đình Huế phải ký một đạo dụ vào năm 1888 . Theo dụ này, những người nước ngoài thường trú ở An Nam có quyền sở hữu và chuyển nhượng đất đai ở khu vực Trường Sơn mà không cần nộp tiền hoặc chỉ nộp một khoản phí nhỏ mang tính chất tượng trưng. Kết quả là nhiều đồn điền của các điền chủ người Pháp đã mọc lên, ví dụ như: Các cánh đồng lúa và đồn điền mía đường của Borel và Richardson ở An Diệm; Các đồn điền trồng lúa và trang trại quế ở Trà $\mathrm{My}$; Đồn điền cà phê và cao su Delignon-Paris ở An Khê; và Một nông trang trồng lúa và thuốc lá gần Quy Nhơn... Mười một năm sau, bằng một đạo dụ ban hành ngày 28 tháng 4 năm 1899, triều đình Huế đã đồng ý bàn giao quyền cấp quyền sử dụng đất cho chính quyền thực dân (Hickey, 1982, tr. 274; Phan, 1961, tr. 409). Ngày 16 tháng 10 cùng năm, người Pháp buộc vua Đồng Khánh (1885-1889) ký một tuyên cáo, giao cho họ toàn quyền tổ chức hệ thống hành chính thuộc địa và trực tiếp cai trị các dân tộc thiểu số ở Tây Nguyên (Cửu \& Toan, 1974, tr. 132; Lê, 2006, tr. 401-449).

Cũng trong thời kỳ đó, Quốc vương Xiêm, sau khi kiểm soát miền Nam Lào, bắt đầu đưa ra những yêu sách đối với một số vùng đất gần Tây Nguyên do Pháp đang nắm giữ. Trong bối cảnh đó, một người Pháp gốc đảo Corse tên là Charles-Marie David de Mayréna đã xin đi khám phá Tây Nguyên để tiếp cận các dân tộc thiểu số. Đề nghị này được Toàn quyền Đông Dương Ernest Constans chấp thuận vào năm 1888. Nhờ các kỹ năng bắn súng, đấu kiếm, và hùng biện, Mayréna đã được một số làng người Thượng mời làm trưởng làng trong thời gian ông lưu trú ở Kon Tum. Với sự giúp đỡ của viên Công sứ Bình Định và các vị giáo sĩ từ Quy Nhơn đến Kon Tum như Pierre Irigoyen 
(1856-1935) và Jean Baptiste Guerlach (1858-1912), Mayréna đã thuyết phục được người $\mathrm{Ba} \mathrm{Na}$ và Sédang rằng họ có thể tạo lập một vương quốc riêng. Kết quả là vào ngày 03 tháng 6 năm 1888, Vương quốc Sédang (Royaume des Sédangs) đã ra đời với quốc kỳ, tiền giấy, và các quy định pháp lý riêng; Mayréna tự phong cho mình là Vua Marie đệ nhất (Marie Premier, Roi des Sédangs) (Lê, 2019). Tuy nhiên, do vị "quốc vương" này ngày càng bộc lộ tư tưởng ly khai nên trong thời gian ông trở về châu Âu để xin viện trợ từ các cường quốc phương Tây, chính phủ Pháp đã phái Công sứ Quy Nhơn, Edmond Guiomar, lên Kon Tum giải tán Vương quốc Sédang và cũng là giành lại quyền kiểm soát vùng đất Tây Nguyên. Vương quốc Sédang bị xóa tên sau một năm thành lập, do vậy, Tây Nguyên, từ năm 1889, được đặt dưới quyền quản lý của Công sứ Quy Nhơn. Sau khi từ châu Âu trở lại "vương quốc" của mình, vị "quốc vương" này đã bị chính phủ Pháp cấm nhập cảnh vào Đông Dương. Cái chết của Mayréna không lâu sau đó (vào ngày 11 tháng 11 năm 1890) tại Tioman (một hòn đảo nhỏ trong vịnh Thái Lan) đã đặt dấu chấm hết cho cuộc đời đầy phiêu lưu ông (Lê, 2006, tr. 401- 449).

Trong những năm cuối thế kỷ XIX, vin vào những điều chỉnh trong chính sách cai trị, các nhà cầm quyền thuộc địa ${ }^{5}$ đã tìm nhiều cách khác nhau để sa thải các nhân viên người Việt Nam từng làm trung gian trong các hoạt động thương mại ở vùng đồng bào thiểu số nhưng bị cáo buộc lạm dụng sự tín nhiệm của người Thượng. Từ đó về sau, quan chức hàng tỉnh trong chính quyền thực dân trực tiếp làm việc với các cộng đồng địa phương, chỉ trừ một số ít những cuộc đàm phán phức tạp (Paul, 1966, tr. 74-75). Để thúc đẩy các hoạt động thương mại giữa người Thượng với người Kinh, một số chợ địa phương đã được lên kế hoạch thành lập và đặt dưới sự giám sát của đại diện của công sứ các tỉnh (Hickey, 1982, tr. 274).

Sang đầu thế kỷ XX, sau khi về cơ bản "bình định" các hoạt động kháng chiến dưới ảnh hưởng của ngọn cờ Cần Vương, thực dân Pháp liên tiếp thành lập nhiều đồn quân sự và cơ quan hành chính để cai trị các vùng dân tộc thiểu số. Năm 1900, đồn An Lão (nay thuộc Bình Định) được xây dựng. Năm sau đó, chính quyền thực dân thành lập đại diện hành chính ở Trà My và đồn quân sự tại Ba Tơ, Lang Ri, Minh Long, và Nước Vong để kiểm soát các nhóm người Thượng. Năm 1904, một trụ sở hành chính được thiết lập ở Ninh Hòa để cai trị các dân tộc thiểu số ở khu vực M'drac và tỉnh Khánh Hòa. Năm 1905, Sơn Phòng Trấn (một đơn vị hành chính được hình thành từ thời các chúa Nguyễn, chạy dọc theo dãy Trường Sơn, bao gồm các huyện miền núi của năm tỉnh từ Quảng Nam đến Bình Thuận) và các hệ thống phòng thủ chống lại sự xâm nhập của các nhóm thiểu số đã chính thức bị bãi bỏ (Cửu \& Toan, 1974, tr. 132-133). Tại các khu vực mà hoạt động bình định đã đạt được thành công đáng kể, các chức vụ hành chính quân sự được chính quyền thực dân chuyển đổi thành các cơ quan hành chính dân sự.

\footnotetext{
${ }^{5}$ Khâm sứ Trung Kỳ (Résident of Supérieur de l'Annam) là đại diện chính thức của chính phủ bảo hộ Pháp tại triều đình Huế. Về danh nghĩa, viên chức này không có quyền can dự vào chính trị nội bộ của chính phủ Nam triều, nhưng trên thực tế ông ta mới là người có quyền lực cao nhất ở Trung Kỳ. Khâm sứ Trung Kỳ thậm chí còn có quyền phê chuẩn tất cả các sắc lệnh của Hoàng đế Việt Nam trước khi các văn bản này được công bố.
} 


\subsubsection{Nhũng thay đổi trong chính sách dân tộc của Pierre Marie Antoine Pasquier}

Ngày 30 tháng 7 năm 1923, Khâm sứ Trung Kỳ (Résident of Supérieur de l'Annam) Pierre Marie Antoine Pasquier ban hành Nghị định số 578-ca về chính sách của chính quyền thuộc địa đối với cộng đồng người Tây Nguyên. Nghị định này quy định nguyên tắc hỗ trợ người Thượng; Ngăn chặn người Việt định cư ở Tây Nguyên; Hạn chế giới chủ đồn điền khai thác quá mức sức lao động của người bản xứ, dưới tác động của chính sách này, ở những khu vực đã được bình định, người Pháp tìm cách cắt đứt mối quan hệ giữa người Thượng và các cộng đồng bên ngoài (bao gồm người Việt, người Khmer, người Chăm, người Lào, và cả nhà thờ Công giáo); Tôn trọng phong tục và truyền thống của người Thượng; Xây dựng đường sá, trường học, và chợ; Bố trí nơi định cư và đào tạo cho người dân những kỹ thuật hữu ích trong canh tác nông nghiệp; Điều chỉnh hạn mức lao động bắt buộc và diện tích đối với các đồn điền trồng cây công nghiệp; Tuyển dụng và huấn luyện binh sĩ và công chức người Thượng; Thiết lập các đồn binh và bộ máy hành chính; Đàn áp các phong trào nổi dậy đòi quyền tự chủ; Và tổ chức buổi lễ truyền thống hàng năm để đón nhận sự quy thuận của những người Thượng từng chống đối chính quyền thực dân (Cửu \& Toan, 1974, tr. 133). Pasquier lấy vùng Đắk Lắk, nơi Sabatier cầm quyền, làm khuôn mẫu cho các quan chức người Pháp ở Tây Nguyên học tập.

Từ khi được cử đến làm Công sứ Đắk Lắk vào năm 1914, Léopold Sabatier chủ trương "Đất Tây Nguyên của người Tây Nguyên", coi đó là "nguyên lý chỉ đạo trong việc cai trị các xứ Mọi" và không cho phép các nhóm người khác đến khai thác (Lê, 2006 , tr. 407-450). Trong 12 năm cầm quyền, ông sống như một người đàn ông $\hat{\mathrm{E}}$ Đê (Rhade), giao tiếp và xử lý các vấn đề hành chính bằng tiếng Ê Đê, thậm chí kết hôn với con gái của tù trưởng người địa phương Kun $\mathrm{Yu}$ Nob (người Jarai). Sabatier cũng tổ chức xây dựng trường học, đường sá, bệnh viện, và các nhà máy điện ở Đắk Lắk. Trong thời gian 1923-1925, nhận được sự khích lệ của viên Công sứ Đắk Lắk, một giáo viên người $\hat{E}$ Đê tại trường tiểu học Pháp-E Đê ở Buôn Mê Thuột tên là Y Jut ${ }^{6}$ và hai đồng nghiệp của ông là $\mathrm{Y}$ Jut Hwing và $\mathrm{Y} U \mathrm{U}$ đã sáng tạo ra bảng chữ cái $\hat{\mathrm{E}}$ Đê trên cơ sở Latin hóa tiếng nói địa phương. Cũng trong năm 1923, Sabatier đã truyền cảm hứng cho Y Say ghi lại luật tục ÊE Đê khi ông chứng kiến một già làng điều khiển một phiên tòa theo luật tục địa phương. Dựa trên những ghi chép này, năm 1927, Y Say và Y Út đã chính thức công bố luật tục Ê Ể bằng cả tiếng Ê Đê và tiếng Pháp (Cửu \& Toan, 1974, tr. 134; Hickey, 1982, tr. 298).

Những đóng góp của Sabatier trong việc sưu tầm, giới thiệu văn hóa cổ truyền, và cải thiện cơ sở hạ tầng trong vùng người Thượng, nơi ông ta cai trị, là rất đáng ghi nhận. Tuy nhiên, để huy động nguồn lực tài chính tại chỗ cho các dự án kinh tế-xã hội, ngay sau khi được bổ nhiệm làm công sứ đầu tiên của Đắk Lắk, Sabatier đã tìm cách tăng mức thuế suất. Do đó, thu nhập từ thuế hàng năm của tỉnh này tăng nhanh, đạt tới

${ }^{6} \mathrm{Y}$ Jut cũng là người khởi xướng và lãnh đạo một phong trào chống Pháp của các trí thức người thiểu số ở Tây Nguyên trong những năm 1925-1926. 
30,000 piasters ${ }^{7}$ so với số tiền 3,000 đến 4,000 mỗi năm trước Thế chiến I (Hickey, 1982, tr. 273, 300). Gánh nặng thuế khóa này đã châm ngòi cho nhiều hoạt động đấu tranh phản kháng của các nhóm cư dân Thượng, tiêu biểu là phong trào do Y Ut khởi xướng.

Nỗ lực trong việc thực hiện chủ trương "Đất Tây Nguyên của người Tây Nguyên" của Sabatier, sau cùng, không mang lại kết quả như mong đợi. Do những việc làm của viên công sứ này đã vượt ra ngoài mục tiêu của nhà cầm quyền thuộc địa, năm 1925, chính quyền Liên bang Đông Dương đã điều ông đi nơi khác để mở đường cho giới điền chủ người Pháp thao túng đất đai ở Đắk Lắk.

\subsubsection{Nhũ̃ng sủa đổi trong chính sách dân tộc được thục hiện bởi Georges Thierry} d'Argenlieu

Tháng 8 năm 1945, Tổng thống Pháp bổ nhiệm Đô đốc Georges Thierry d'Argenlieu làm Cao ủy (để thay thế cho chức danh Toàn quyền) và Tướng Philippe Leclerc de Hauteclocque làm chỉ huy lực lượng viễn chinh Pháp ở Đông Dương. Chỉ ba tuần sau khi Việt Nam tuyên bố độc lập, với sự giúp đỡ của quân đội Anh, quân viễn chinh Pháp đã nổ súng ở Sài Gòn vào ngày 23 tháng 9 năm 1945 nhằm tái chiếm bán đảo Đông Dương ${ }^{8}$.

Với ưu thế vượt trội về trang bị, lực lượng viễn chinh Pháp đã nhanh chóng điều động các tiểu đoàn cơ động để chiếm lại Nam Trung Kỳ và Nam Kỳ. Cuối tháng 06 năm 1946, Pháp huy động Lữ đoàn Viễn Đông số 1 và các tiểu đoàn người Thượng tái chiếm các phần còn lại của Tây Nguyên như Buôn Mê Thuột, Kon Tum, Pleiku, Cheo Reo, An Khê, Đăk Tô, Đăk Sut, Đăk Glé... (Cửu \& Toan, 1974, tr. 136). Đối đầu với những đội quân tinh nhuệ, lực lượng Việt Minh chủ động lựa chọn chiến thuật du kích, tăng cường tuyển mộ các chiến binh Thượng, tổ chức các căn cứ huấn luyện kỹ thuật chiến đấu ở vùng sâu vùng xa, và bất ngờ phục kích để làm tiêu hao sinh lực và ý chí của kẻ thù.

Để phá vỡ ý thức cộng đồng về một quốc gia thống nhất của người Việt Nam, D'Argenlieu đã áp dụng triệt để chính sách "chia để trị”". Vào ngày 31 tháng 10 năm 1945, ngay sau khi đến Sài Gòn, viên Cao ủy đã tổ chức lại Liên bang Đông Dương, đưa Đông Dương vào khối Liên hiệp Pháp (Union française). Ông cũng thành lập cái gọi là Cộng hòa tự trị Nam Kỳ (République autonome de Cochinchine) vào ngày 26 tháng 05 năm 1946 (Đoàn, 1966, tr. 23-24). Đối với Tây Nguyên, vào ngày 27 tháng 5

\footnotetext{
${ }^{7}$ Đồng bạc Đông Dương do người Pháp cho phát hành ở Đông Dương trong giai đoạn 1885 - 1954.
}

${ }^{8}$ Trong nghiên cứu nổi tiếng của mình về cuộc kháng chiến chống Pháp của nhân dân Việt Nam (mà ông gọi là cuộc Chiến tranh Đông Dương lần thứ nhất), nhà sử học người $\mathrm{Na}$ Uy Stein Tonnesson trình bày một quan điểm được cho là thú vị và mới mẻ về những lý do bùng nổ của cuộc chiến. Theo Tonnesson, các tướng lĩnh Quốc dân đảng Trung Quốc đã có vai trò đáng kể trong hoạt động môi giới cả hai phía (Pháp và Việt Nam) trong cuộc đàm phán để đi đến một thỏa thuận sơ bộ được ký ngày 06 tháng 3 năm 1946. Bất chấp thực tế là sau năm 1945, trong khi Paris chỉ muốn bảo vệ lợi ích của Pháp ở miền Nam, các quan chức Pháp ở Đông Dương đã lên kế hoạch giành quyền kiểm soát lâu dài toàn bộ Việt Nam khi họ tiến ra miền Bắc để thay thế quân đội Quốc dân đảng Trung Quốc. Nếu không có áp lực mạnh mẽ từ phía Quốc dân đảng Trung Quốc để đi đến việc ký kết thỏa thuận sơ bộ, cuộc chiến có thể đã bùng nổ vào đầu năm 1946. Cũng theo Tonnesson, các quan chức Pháp ở Đông Dương đã cố tình hành động chống lại chỉ thị của Paris khi họ tìm mọi cách khiêu khích để quân đội Việt Minh tấn công trước. Quân đội Việt Minh đã cố gắng kiềm chế, không trả đũa các hành động khiêu khích của quân Pháp trong một thời gian, nhưng cuối cùng họ đã mất bình tĩnh và khai hỏa vào ngày 19 tháng 12 (Tonnesson, 2009). 
năm 1946, D'Argenlieu đã ban bố một sắc lệnh dành cho khu vực này một cơ chế hành chính đặc biệt, biến Tây Nguyên thành một khu tự trị của người Thượng (Pays Montagnard du Sud Indochinois). Khu hành chính đặc biệt này bao gồm các tỉnh: Đắk Lắk, Đồng Nai Thượng (Haut Donnai), Langbian, Pleiku, và Kon Tum, với trung tâm hành chính là Buôn Mê Thuột. Khu tự trị Tây Nguyên được quản lý bởi một đại biểu đặc biệt (Commissariat des Populations Montagnardes du Sud-Indochinois-P.M.S.I.) của chính quyền Liên bang Đông Dương. Với việc ban hành sắc lệnh trên d'Argenlieu hy vọng sẽ mở ra một trang sử mới. Tây Nguyên, từ đây, sẽ trở thành một "con tốt trong chiến lược chính trị của người Pháp ở Đông Dương”. Bản sắc lệnh cũng chính thức tách Tây Nguyên khỏi Trung Kỳ và đặt vùng đất này dưới sự kiểm soát trực tiếp của Pháp, tương tự như Cộng hòa tự trị Nam Kỳ. Mặt khác, vào ngày 16 tháng 5 năm 1946, d'Argenlieu lên Buôn Mê Thuột để tổ chức một buổi lễ tuyên thệ. Tại đó, một số tù trưởng người thiểu số như Nay Nui, Y Ut Nie Buôn Rit, và Khunjanob đã thề trung thành với Pháp (Cửu \& Toan, 1974, tr. 136-137; Đoàn, 1966, tr. 24; Hickey, 1982, tr. 393).

Để đào tạo đội ngũ sĩ quan quân đội người bản xứ, chính quyền thuộc địa đã thành lập một trường quân sự ở Huế vào tháng 12 năm 1948 (Trường Sĩ quan Việt Nam-thường được gọi là Trường Võ bị Huế); Hai năm sau trường này được dời lên Đà Lạt với tên gọi mới là École Militaire Interarmes (tức Trường Võ bị Liên quân Đà Lạt). Cũng trong thời kỳ đó, việc thành lập Ecole de l'Air (Trường Không quân) và một trung tâm đào tạo hải quân ở Nha Trang đã đánh dấu sự ra đời của không quân và hải quân của "Quân đội Quốc gia Việt Nam” lúc bấy giờ.

Tương tự như các thời kỳ trước, sau Chiến tranh thế giới thứ hai, chính phủ Pháp tiếp tục tài trợ cho các nghiên cứu về các dân tộc thiểu số ở miền Nam Đông Dương. Là một phần trong các dự án nghiên cứu của Trung tâm Nghiên cứu Khoa học và Thuộc địa (Centre des Recherches Scientifique et Coloniale), Georges Condominas trở lại Tây Nguyên vào năm 1948 để thực hiện nghiên cứu dân tộc học về người M'nong Gar ở Sar Luk, một ngôi làng hẻo lánh nằm ở phía nam tỉnh Đắk Lắk. Do thành thạo ngôn ngữ địa phương, Condominas có thể tham dự các sinh hoạt hàng ngày của dân làng và thực hiện các cuộc khảo sát mà không cần đến người phiên dịch. Từ những kiến thức và kinh nghiệm thu thập được qua các chuyến điền dã, ông đã cho xuất bản nhiều công trình khoa học về người M'nong Gar, trong số đó có những tác phẩm được giới dân tộc học đánh giá cao như: Nous avons mangé la forêt (tạm dịch là Chúng tôi đã ăn rù̀ng đá thần Gôo) và L'exotique est quoteidien: Sar Luk, Vietnam Central (tạm dịch là Cái xa la là cái hàng ngày: Sar Luk, miền Trung Việt Nam).

Sau Cách mạng tháng Tám, phần lớn công nhân trong các đồn điền, công chức, và giáo viên đã rời bỏ các nhà cai trị thực dân để về với lực lượng Việt Minh. Cũng trong giai đoạn này, lập trường chính trị của lực lượng trí thức người Thượng có sự phân hóa rõ rệt. Trong khi một bộ phận chọn con đường tiếp tục phục vụ cho chính quyền thực dân, như Y Sok Eban, Y Tuic Mlo Duon Du, Y Blieng Hmok, Touprong Hiou, Touprong Ya Ba, Touneh Han Din, Ya Yu Sahau, và Bahnaria Ya Don, thì nhiều người khác đã giác ngộ lý tưởng cách mạng và trở về chiến đấu cho độc lập dân tộc như Y Ngong, $\mathrm{Y}$ Bih Aleo, Y Wang, Y Nue, Y Tlam, Phem, Depp... (Hickey, 1982, tr. 390). 
Trong bối cảnh đó, vào tháng 4 năm 1946, Việt Nam Dân chủ Cộng hòa đã triệu tập Đại hội Dân tộc Thiểu số miền Nam ở Kon Tum. Tại hội nghị, một lá thư của Chủ tịch Hồ Chí Minh đã được công bố nhằm giải thích về lập trường của chính phủ Việt Nam Dân chủ Cộng hòa đối với các nhóm dân tộc thiểu số ở miền Nam Việt Nam. Theo đó, những tộc người như Pako, Cơ Tu, Hré, Giẻ Triêng, Sédang, Ba Na, M'nong, Cill, $\mathrm{K}$ 'ho... đều được đối xử như những người anh em ruột thịt của người Kinh và của các dân tộc thiểu số khác trên cả nước (Hồ, 1946). Trước đó, chính phủ Việt Nam Dân chủ Cộng hòa cũng đã ban hành một sắc lệnh về việc thành lập Nha Dân tộc thiểu số. Nhiệm vụ của cơ quan này là: "Xem xét các vấn đề chính trị và hành chính thuộc về các dân tộc thiểu số trong nước và thắt chặt tình thân thiện giữa các dân tộc sống trên đất Việt Nam" (Ủy ban Dân tộc, 2012, tr. 3). Các dân tộc thiểu số còn nhận được cam kết về quyền học ngôn ngữ mẹ đẻ tại các trường tiểu học cũng như duy trì các tòa án luật tục truyền thống. Đại diện của các dân tộc thiểu số cũng được quyền tham gia các cuộc bầu cử quốc hội theo hiến định ${ }^{9}$ (Bùi, Trần, \& Bùi, 2006, tr. 249).

Bước vào thập niên 1950, trước sự lớn mạnh của lực lượng kháng chiến, quân Pháp phải rút hầu hết lực lượng viễn chinh ở Tây Nguyên để củng cố chiến trường phía Bắc. Để ngăn chặn các cuộc tấn công của quân đội Việt Nam Dân chủ Cộng hòa tại các thị xã ở Tây Nguyên như Buôn Mê Thuột, Kon Tum, Pleiku, và Đà Lạt, cùng với việc xây dựng thêm các đồn bốt mới, tháng 3 năm 1951, chính quyền thực dân đã thành lập Sư đoàn 4 bộ binh (còn gọi là Sư đoàn Thượng quân). Sư đoàn này hoạt động trải dài từ Đắk Pék (phía bắc Kon Tum) đến tỉnh Phan Thiết, giáp với phía nam Tây Nguyên. Với 9,000 quân, Sư đoàn 4 được phiên chế thành ba tiểu đoàn bộ binh bản xứ (tiểu đoàn 1 , 2 , và 7 ) và một tiểu đoàn hỗn hợp giữa binh lính người Kinh và người Thượng (tiểu đoàn 28) (Moore, 2007, tr. 70).

Dựa trên Hiệp định Elysée (Accords de l'Elysée) (được ký ngày 08 tháng 3 năm 1949 giữa cựu hoàng Bảo Đại và Tổng thống Pháp), ngày 15 tháng 4 năm 1950, Bảo Đại ban hành Đạo du số 06, tách Tây Nguyên ra khỏi lãnh thổ Quổc gia Việt Nam và lập quy chế hành chính đặc biệt có tên là "Hoàng triều Cương thổ" (Domaine de la Couronne du Pays Montagnards du Sud). Ở Hoàng triều Cương thổ, Bảo Đại vừa giữ vai trò Quốc trưởng lại vừa là Hoàng đế (Thái, 2003, tr. 99). Cũng theo đạo dụ này, có hai Hoàng triều Cương thổ ở các vùng cao nguyên miền Bắc và miền Nam Việt Nam do một viên Khâm Mạng cai quản ${ }^{10}$. Trong một diễn biến tiếp theo, sau khi Pháp trao quyền quản lý vùng đất Hoàng triều Cương thổ cho chính phủ Quốc gia Việt Nam vào ngày 30 tháng 5 năm 1950, ngày 05 tháng 7 , Quốc trưởng Bảo Đại tiếp tục ban hành Sắc lệnh số 03 , gộp các tỉnh Đắk Lắk, Đồng Nai Thượng, Lâm Viên (Langbian), và Pleiku, lập thành một địa phận hành chính riêng, gọi là miền Nam thuộc Hoàng triều Cương thổ. Toàn bộ vùng lãnh thổ này do một Ủy viên Đức Quốc trưởng cai quản, dưới

\footnotetext{
${ }^{9}$ Trong số 34 đại biểu dân tộc thiểu số (trên tổng số 333 đại biểu tham dự Quốc hội năm 1946) có một số đến từ các tỉnh phía Nam như Y Ngông Niê Kdăm, Y Wang Mlô Duôn Du, Nay Phin, Recom Rock, Tuprong Hiếu... (Quốc hội, 2019).

${ }^{10}$ Về danh nghĩa thì Hoàng triều Cương thổ ở khu vực miền núi phía Bắc bao gồm vùng lãnh thổ mà ở đó "các dân tộc không thuộc giống nòi Việt Nam mà khu vực cư trú lịch sử vẫn trên lãnh thổ Việt Nam và theo truyền thống vẫn quy thuận Hoàng triều" (Cửu \& Toan, 1974, tr. 137). Tuy nhiển, trên thực tế cho đến năm 1950, Pháp chỉ kiểm soát được một phần nhỏ "Hoàng triều Cuơng thổ miền Bắc”, phần lớn địa bàn cư trú của các dân tộc thiểu số ở đây vẫn do chính quyền Việt Nam Dân chủ Cộng hòa nắm giữ.
} 
quyền của Tòa Khâm mạng (đứng đầu là một viên Khâm mạng), và được giám sát bởi một Quốc vụ khanh (Cửu \& Toan, 1974, tr. 137; Po, 2012, tr. 11; Salemink, 2002, tr. 6).

Vào ngày 21 tháng 5 năm 1951, Đổng lý văn phòng của Quốc trưởng Bảo Đại ra Đạo du 16/QT/TD, ban hành một quy chế đặc biệt (statut particulier) gồm chín điều cho Hoàng triều Cương thổ (Đoàn, 1966, tr. 94). Điều một của đạo dụ này dành cho cộng đồng người Thượng "các quyền ưu việt" và được phát triển theo phong tục của riêng họ. Điều hai và ba khuyến khích người Thượng tham gia vào hệ thống hành chính, chính trị, tư pháp ở Tây Nguyên, đặc biệt là tham gia vào các tòa án phong tục. Các điều tiếp theo đề cập đến việc thành lập một hội đồng kinh tế ở Tây Nguyên (Điều bốn); Về quyền của chủ đất (Polăn) và vai trò của luật tục cũng như các tù trưởng địa phương trong các giao dịch mua bán, trao đổi đất đai (Điều năm); Về vai trò của chính phủ trong các kế hoạch phát triển kinh tế, văn hóa, và xã hội ở vùng đồng bào thiểu số (Điều sáu); Về yêu cầu bắt buộc của việc dạy thổ ngữ trong các bậc sơ học và tiểu học (Điều bảy); Đào tạo cán bộ người Thượng trong các lĩnh vực hành chính, y tế, kinh tế, văn hóa, và xã hội theo yểu cầu của từng địa phương (Điều tám); Về chế độ quân dịch đặc thù (không gắt gao) đối với người Thượng; Các đơn vị sơn cước được ưu tiên phục vụ tại Tây Nguyên (Điều chín) ${ }^{11}$ (Cửu \& Toan, 1974, tr. 138; Đoàn, 1966, tr. 94; Touneh, 1970, tr. 92-97).

Ngày 04 tháng 4 năm 1952, Quốc trưởng Bảo Đại tiếp tục ban hành Đạo du 27/QT/TD về Tây Nguyên. Với dụ này, một Hội đồng Kinh tế và Xã hội cho Tây Nguyên được thành lập dưới sự điều hành của nội các, do Quốc trưởng đứng đầu ${ }^{12}$ (Đoàn, 1966, tr. 109). Theo kế hoạch của chính phủ, nhiều đồn điền cà phê, chè, cao su, và mía sẽ được mở rộng hoặc thành lập mới để khai thác hiệu quả nguồn đất bazan và khí hậu nhiệt đới của Tây Nguyên. Cùng với các mục tiêu kinh tế, các chương trình của chính phủ cũng tập trung vào việc cải thiện tập quán sinh hoạt của người dân bằng cách khuyến khích họ sử dụng đèn thắp sáng, may quần áo, đồ gia dụng, và xà phòng. Các phương pháp phòng và chữa bệnh dựa trên liệu pháp khoa học sẽ thay thế dần cho phương thức cầu cúng được thực hiện bởi các vị pháp sư. Mỗi làng sẽ có trường học, chợ, nhà cộng đồng, bệnh xá, và cửa hàng riêng.

Với sự ra đời của Hoàng triều Cương thổ, về danh nghĩa người Pháp đã công nhận chủ quyền của Việt Nam đối với Tây Nguyên, tuy nhiên trên thực tế họ vẫn duy trì một "quy chế riêng biệt"" (statute particular). Thông qua những "nghĩa vụ đặc biệt" và "các đại biểu đặc biệt", chính quyền thực dân vẫn tiếp tục giữ ảnh hưởng đối với vùng đất này. Bằng "giải pháp Bảo Đại", "mẫu quốc" đã tương đối thành công trong việc lợi dụng vị cựu hoàng và mối quan hệ truyền thống giữa triều đình Huế với Vua Nước và Vua Lửa để tập hợp các thủ lĩnh người thiểu số có tư tưởng thân Pháp ${ }^{13}$. Sự gặp gỡ của

\footnotetext{
${ }^{11}$ Du số 16/QT/TD. Trong Hồ sơ về các hoạt động của Cao nguyên miền Nam 1952-1954. Trung tâm Lưu trữ Quốc gia IV, Đà Lạt. Kí hiệu hồ so: 66, V1.

${ }^{12}$ Du số 27/QT/TD. Trong Hồ sơ về các hoạt động của Cao nguyên miền Nam 1952-1954. Trung tâm Lưu trữ Quốc gia IV, Đà Lạt. Kí hiệu hồ sơ: $66, \mathrm{~V} 2$.

${ }^{13}$ Trước những diễn tiến của cuộc Kháng chiến của nhân dân Việt Nam theo hướng bất lợi cho Pháp, kèm theo các gói hỗ trợ tài chính và trang thiết bị quân sự, Washington cũng yêu cầu Paris phải đẩy mạnh việc tìm kiếm một "giải pháp chính trị" cho Đông Dương. Theo đó, tháng 01 năm 1949, Bộ Ngoại giao Hoa Kỳ gây sức ép, buộc Pháp phải đàm phán với cựu hoàng Bảo Đại để đi đến thành lập Chính phủ Quốc gia Việt Nam. Kết quả là ngày 08 tháng 3 năm 1949, Pháp đã ký Hiệp ước Elysée với Bảo Đại. Theo
} 
các vị tù trưởng địa phương trong các sự kiện văn hóa liên làng, cũng như giữa con cháu họ, những người đang học tập trong các trường tiểu học Pháp-Bản xứ, hoặc đang là binh lính trong các đơn vị quân đội thuộc địa, đã bước đầu làm nảy sinh ý thức về một bản sắc văn hóa chung của cộng đồng người Tây Nguyên. Dù cho, đó mới chỉ là quá trình trao đổi ngôn ngữ và văn hóa giữa các sắc tộc và có thể bao gồm mối quan hệ hôn nhân đan xen giữa các gia đình thượng lưu. Cũng trong lòng tầng lớp thượng lưu mới ra đời ở Tây Nguyên, văn hóa Pháp cùng với tinh thần hợp tác với chế độ thực dân ngày càng lan rộng.

\subsection{Một số điểm nổi bật trong chính sách dân tộc của chính quyền thuộc địa ở Tây Nguyên}

Nhằm mục đích tăng ngân sách Đông Dương nhanh chóng, sau khi được bổ nhiệm làm Toàn quyền vào đầu năm 1897, Paul Doumer đã áp dụng chính sách thuế quan mới. Theo đó, các mặt hàng được xem là thiết yếu trong các giao dịch thương mại giữa người Thượng và người Kinh như quế, hồi, muối, và gỗ bị áp một mức thuế rất cao. Các loại thuế đinh đã áp dụng trước đó nay được thay thế bằng khoản thuế hàng năm (thuế thân) từ 1.0 đến 1.5 piasters, tùy theo điều kiện kinh tế của mỗi địa phương. Số tiền này áp dụng cho tất cả người Thượng từ mười tám đến sáu mươi tuổi (Hickey, 1982, tr. 273, 300). Trong lĩnh vực nông nghiệp, các quan chức thực dân tuyên bố rằng phương pháp canh tác truyền thống với quy trình phát-đốt-cốt-trỉa của người Tây Nguyên có thể gây xói mòn đất và thu hẹp diện tích rừng. Vì lý do này, họ khuyến khích dân làng chuyển sang định canh cây lúa ở những khu vực có điều kiện tưới tiêu thuận lợi. Ngoài ra, mô hình vườn rau và cây trái của từng hộ gia đình cũng được khuyến khích nhân rộng để bổ sung nguồn thực phẩm. Để tránh những xung đột không mong muốn với cư dân tại chỗ về quyền sở hữu đất đai, chính quyền thuộc địa chủ trương "tôn trọng" các khu vực mà người Tây Nguyên tuyên bố quyền chiếm hữu, đặc biệt là vùng đất mà họ được thừa hưởng từ tổ tiên. Các chủ đồn điền người Pháp đã tỏ ra khá khôn ngoan khi lập các đồn điền bên cạnh những nương rẫy của người Thượng và chia sẻ tài nguyên đất sản xuất với các cư dân tại chỗ. Bằng cách thức này, nhà cầm quyền thực dân đã khiến người Tây Nguyên tin rằng họ sẽ không bị ép buộc phải rời khỏi không gian sinh tồn của tổ tiên mình.

Nhìn nhận hệ thống đường giao thông như là phương tiện tuyệt vời để truyền bá văn minh và thực hiện công cuộc bình định, người Pháp đã nâng cấp các đường mòn xuyên qua các khu rừng ở Tây Nguyên. Và, để củng cố bộ máy hành chính cũng như phát triển kinh tế thuộc địa, một số thị xã đa chức năng kiểu đô thị phương Tây đã được hình thành tại trung tâm các khu vực đông dân cư như Pleiku ${ }^{14,15}$, Kon Tum, Buôn Mê

\footnotetext{
đó, nước Pháp đồng ý trao độc lập về danh nghĩa cho Quốc gia Việt Nam với điều kiện quốc gia này vẫn nằm trong khối Liên hiệp Pháp (Pentagon, 1971a, tr. 1-51). Tuy nhiên, sau khi nhận thấy "Bảo Đại đã không hoàn thành vai trò của mình một cách đáng xấu hổ và thu động" và "Quyền lực đã bị thâu tóm bởi các chính trị gia không xúng đáng"; "Quân đội bất lục và phụ thuộc hoàn toàn vào các chỉ huy người Pháp”, Mỹ đã ngừng ủng hộ "Giải pháp chính trị” này (Pentagon, 1971b, tr. 53-75).

${ }^{14} \mathrm{Nghị} \mathrm{định} \mathrm{ngày} 04$ tháng 7 năm 1905 về việc thành lập tỉnh Plei-kou-Derr (Dương, 2001, tr. 297).

${ }^{15}$ Nghị định ngày 25 tháng 4 năm 1907 của Toàn quyền Đông Dương bãi bỏ Nghị định ngày 04 tháng 7 năm 1905 về việc thành lập tỉnh Plei-kou-Derr (Trung Kỳ) (Trung tâm Lưu trữ Quốc gia I, 2013, tr. 202 -232).
} 
Thuột, Đắk Lắk, Cheo Reo, và Đà Lạt. Cũng cần phải nói thêm rằng, để phát huy cao nhất hiệu quả quản lý, từ sau khi được thành lập, tên gọi và địa giới hành chính của các tỉnh ở Tây Nguyên cũng như các đại lý và trung tâm tỉnh lỵ được điều chỉnh khá nhiều lần dưới các đời Toàn quyền khác nhau.

Cụ thể là theo Nghị định ngày 04 tháng 7 năm 1905, một tỉnh tự trị mang tên Pleiku (Plei-kou-Derr), bao gồm các khu vực cư trú của người Sédang, Ba Na, và Jarai từ phía tây tỉnh Bình Định trở ra được thành lập. Tuy nhiên, hai năm sau, Toàn quyền Đông Dương lại ban hành một nghị định bãi bỏ tỉnh Pleiku. Toàn bộ đất đai của tỉnh này được chia làm hai phần: Một phần được đặt thành Đại lý Kon Tum, tái sáp nhập vào tỉnh Bình Định, và nằm dưới sự quản lý của Công sứ Bình Định ${ }^{16}$; Phần còn lại trở thành Đại lý Cheo Reo, được sáp nhập vào tỉnh Phú Yên, và do Công sứ Phú Yên cai trị $^{17}$. Các địa giới vừa được xác lập cũng chỉ tồn tại chưa đầy tám năm. Ngày 09 tháng 02 năm 1913, Toàn quyền Đông Dương tiếp tục ban hành một nghị định điều chỉnh tên gọi và địa giới hành chính ở phía Bắc Tây Nguyên. Cụ thể là khu vực Pleiku cũ được tái lập và một tỉnh tự trị mang tên Kon Tum được thành lập với các trung tâm hành chính là Cheo Reo, Kon Tum, và Đắk Lắk. Tỉnh Đắk Lắk bị hạ cấp xuống thành Đại lý Đắk Lắk và là trung tâm hành chính của tỉnh Kon Tum mới. Trụ sở của trung tâm hành chính mới được đặt tại Buôn Mê Thuột; Trung tâm hành chính Kon Tum trước đây bị xóa bỏ ${ }^{18}$. Ngày 28 tháng 3 năm 1917, Toàn quyền Đông Dương ban hành một nghị định cắt hai tổng Tân Phong và An Khê thuộc cao nguyên An Khê (tỉnh Bình Định) để sáp nhập vào Kon Tum. Đến ngày 14 tháng 11 cùng năm, Đại lý $A n$ Khê được thành lập và đặt dưới quyền quản lý của Công sứ Kon Tum. Tám năm sau, vào ngày 24 tháng 5 năm 1925, Đại lý Pleiku được thành lập, cũng do Công sứ Kon Tum cai trị. Năm 1929, các thị xã Pleiku và Kon Tum ra đời; Ba năm sau đó, tỉnh Pleiku chính thức được thành lập (Dương, 2001, tr. 340).

Trong một diễn biến tương tự, ngày 06 tháng 01 năm 1916, Toàn quyền Đông Dương ban hành nghị định thành lập tỉnh Lâm Viên (Langbian) ${ }^{19}$. Tỉnh lỵ của đơn vị hành chính mới thành lập này được đặt tại Đà Lạt. Các đơn vị hành chính trực thuộc bao gồm Đại lý Đà Lạt và Đại lý Di Linh (vừa được tách từ tỉnh Bình Thuận). Tuy nhiên, đến ngày 31 tháng 10 năm 1920, Toàn quyền Đông Dương lại ra một nghị định, xóa bỏ tỉnh Lâm Viên. Địa bàn của tỉnh này được chia tách làm hai phần: Một phần lập thành thành phố Đà Lạt ${ }^{20}$, phần còn lại lập thành tỉnh Đồng Nai Thượng (Haut Donnai) với

\footnotetext{
${ }^{16}$ Nghị định ngày 12 tháng 6 năm 1907 của Toàn quyền Đông Dương quyết định thành lập Trung tâm Hành chính tại Kon Tum, tỉnh Quy Nhơn (Trung Kỳ) (Trung tâm Lưu trữ Quốc gia I, 2013, tr. 237).

${ }^{17}$ Nghị định ngày 12 tháng 6 năm 1907 của Toàn quyền Đông Dương quyết định thành lập Trung tâm Hành chính tại Cheo Reo, tỉnh Phú Yên (Trung tâm Lưu trữ Quốc gia I, 2013, tr. 237).

${ }^{18}$ Nghị định ngày 09 tháng 02 năm 1913 của Toàn quyền Đông Dương quyết định đặt tỉnh Phú Yên dưới quyền cai trị của Công sứ Bình Định, xóa bỏ tỉnh Phan Rang và tái lập khu vực Plei-kou-Derr cũ thành lập tỉnh tự trị mang tên tỉnh Kon Tum (Trung tâm Lưu trữ Quốc gia I, 2013, tr. 293).

${ }^{19}$ Nghị định ngày 06 tháng 01 năm 1916 của Toàn quyền Đông Dương thành lập tỉnh Langbian (Trung tâm Lưu trữ Quốc gia I, 2013 , tr. 306 - 307)

${ }^{20}$ Nghị định ngày 31 tháng 10 năm 1920 của Toàn quyền Đông Dương quyết định nâng cấp khu tự trị Langbian (cao nguyên Lâm Viên) lên thành phố Đà Lạt (Trung tâm Lưu trữ Quốc gia I, 2013, tr. 340 - 342).
} 
tỉnh lỵ đặt tại Di Linh. Để tăng cường hiệu lực quản lý đối với thành phố Đà Lạt, ngày 30 tháng 7 năm 1926, Toàn quyền Đông Dương tiếp tục ban hành một nghị định, quy định rõ chức năng và nhiệm vụ của các viên công sứ và đốc lý; Cơ cấu tổ chức cũng như chức năng nhiệm vụ của ủy ban thành phố... ${ }^{21}$ Đến ngày 14 tháng 9 năm 1928, Toàn quyền Đông Dương ra nghị định chuyển tỉnh lỵ Đồng Nai Thượng từ Di Linh về Đà Lạt. Và vào ngày 08 tháng 01 năm 1941, một nghị định khác của Toàn quyền Đông Dương lại cho tái thành lập tỉnh Lâm Viên với tỉnh lỵ đặt ở Đà Lạt ${ }^{22}$ (Dương, 2001, tr. 361).

Có lẽ, do đã được trang bị kiến thức cơ bản về phong tục của các dân tộc thiểu số trước khi nhậm chức nên các quan chức hàng tỉnh người Pháp thường khá thành thạo trong xử lý công việc ở vùng người Thượng. Họ hiểu được truyền thống tự trị của các nhóm cư dân tại chỗ ở Tây Nguyên, trong đó, mỗi thủ lĩnh địa phương nắm giữ vai trò quyết định trong những hoạt động quan trọng của cộng đồng của mình. Theo truyền thống, mỗi làng người Thượng là một cộng đồng tương đối độc lập và khép kín, ở đó, một vị già làng giữ vai trò "thẩm phán" trong tất cả các tranh chấp phát sinh dựa trên các quy tắc được quy định trong luật tục ${ }^{23}$. Có thể nói, thế lực chính trị nào nhận được sự ủng hộ từ các già làng sẽ rất thuận lợi trong việc chinh phục mục tiêu kiểm soát dân làng. Thông qua việc ban phát những lợi ích về vật chất cũng như địa vị chính trị - xã hội cho đội ngũ già làng, người Pháp đã biến nhiều thủ lĩnh tinh thần của các cộng đồng người Tây Nguyên thành những công chức cơ sở trong bộ máy hành chính thuộc địa. Từ năm 1904, chính quyền thuộc địa bắt đầu thực hiện cải cách hành chính ở cấp độ làng xã, thường gọi là chính sách “cải lương hương chính". Chính sách này được áp dụng đầu tiên ở $\mathrm{Nam} \mathrm{Kỳ}^{24}$, khởi đầu cho quá trình cải cách bộ máy hành chính cấp cơ sở trên toàn cõi Việt Nam (Nguyễn, 2000, tr. 5). Ở Tây Nguyên, nhiều già làng đã chấp thuận đề nghị của người Pháp, phục vụ với vai trò trung gian giữa người dân trong cộng đồng và những nhà cai trị thực dân. Họ lãnh trách nhiệm thu thuế và tổ chức các đợt lao động cưỡng ép theo yêu cầu của nhà cầm quyền. Để phá vỡ tính tự trị và khép kín trong truyền thống văn hóa các dân tộc thiểu số, các nhà cai trị thực dân cũng thường xuyên tập hợp các thủ lĩnh địa phương có tư tưởng thân Pháp trong các sinh hoạt nghi lễ liên làng. Bằng cách này, người Pháp hy vọng sẽ dần dần làm suy yếu nhận thức về các cộng đồng nhỏ và độc lập nói riêng và xây dựng một khái niệm mới về bản sắc cộng đồng người Tây Nguyên nói chung. Ngoài ra, họ cũng chú trọng hoạt động tuyên truyền để khiến người Tây Nguyên tin rằng "sứ mệnh truyền đạt mệnh lệnh của các vị thần linh"

\footnotetext{
${ }^{21}$ Nghị định ngày 30 tháng 7 năm 1926 của Toàn quyền Đông Dương về việc thành lập và quản lý thành phố Đà Lạt (Trung tâm Lưu trữ Quốc gia I, 2013, tr. 420).

${ }^{22}$ Nghị định ngày 08 tháng 01 năm 1941 của Toàn quyền Đông Dương quyết định thành lập tỉnh Langbian (Lâm Viên) (Trung tâm Lưu trữ Quốc gia I, 2013, tr. 420).

${ }^{23}$ Luật tục là một loại hình qui tắc ứng xử bất thành văn được hình thành trong quá trình hình thành và phát triển lâu dài của một cộng đồng địa phương ở Tây Nguyên. Những qui tắc này có chức năng hướng dẫn và điều chỉnh các mối quan hệ xã hội, quan hệ giữa con người và môi trường xung quanh. Việc áp dụng luật tục trong các trường hợp có tranh chấp, vi phạm thường khá đơn giản và nhanh chóng. Cụ thể, sau khi nghe nguyên đơn và bị đơn trình bày, "thẩm phán" sẽ đưa ra một quy định phù hợp của luật tục, cung cấp các căn cứ để đưa ra quyết định phù hợp nhất với lợi ích của các bên liên quan. Tuy nhiên, cần nói thêm rằng, do được hình thành trong điều kiện nhận thức khoa học còn hạn chế, lại được lưu truyền qua nhiều thế hệ bằng hình thức truyền miệng nên một số nội dung của luật tục còn thiếu nhất quán, chưa đảm bảo tính logic chặt chẽ, hoặc còn thể hiện sự mê tín, dị đoan.

${ }^{24}$ Nghị định ngày 27 tháng 8 năm 1904 của Toàn quyền Đông Dương về việc tổ chức Hội đồng Kỳ mục Nam Kỳ (Trung tâm Lưu trữ Quốc gia I, 2013, tr. 202-206).
} 
đã được trao truyền cho chính quyền thuộc địa, thay vì cho các pháp sư người Thượng như trước đây (Hickey, 1982, tr. 261, 291, 294).

Ngày 13 tháng 7 năm 1913, Toàn quyền Đông Dương Albert Sarraut đã phê chuẩn đề nghị của triều đình Huế về việc duy trì luật tục và hệ thống tư pháp ở vùng Tây Nguyên. Cử chỉ "tôn trọng văn hóa địa phương" này phần nào đã giúp chính quyền thực dân đẩy nhanh tốc độ "bình định” ở vùng người Thượng. Tuy nhiên, để những quy định trong luật tục phù hợp với lợi ích của chủ nghĩa thực dân, các nhà lập pháp ở Đông Dương đã tiến hành điều chỉnh ở một số điều khoản. Cụ thể là họ tập trung vào những quy định liên quan đến nghĩa vụ của người Thượng, trong đó bao gồm định mức lao động bắt buộc phục vụ cho các hoạt động xây dựng đường xá, đồn điền, và nộp thuế (Hickey, 1982, tr. 291, 294).

Nhằm từng bước áp dụng các nguyên tắc pháp lý của "mẫu quốc" ở Tây Nguyên, vào ngày 08 tháng 7 năm 1925, Công sứ Kon Tum, Henri Fournier đề nghị triều đình Huế ban hành một tuyên bố về việc tổ chức lại các tòa án luật tục. Theo đề nghị này, mỗi tòa án phong tục nên được điều hành bởi một thẩm phán người Thượng, một đại diện của công sứ (người Pháp), và mười thủ lĩnh địa phương làm trợ lý thẩm phán (Hickey, 1982, tr. 294). Có thể thấy, trong mô hình tòa án phong tục mới này, quyền lực tư pháp của các thẩm phán người Thượng đã bị thu hẹp đáng kể. Cũng tương đồng với hệ thống tư pháp ở Bắc Kỳ và Trung Kỳ, với nguyên tắc bảo hộ, các phán quyết vẫn được các thẩm phán người Thượng và quan chức Nam triều đưa ra nhưng (những phán quyết này) chỉ có hiệu lực khi có sự chấp thuận từ người đại diện của công sứ ${ }^{25}$.

Liên quan đến hệ thống giáo dục của Pháp ở vùng dân tộc thiểu số, các nhà thực dân tin rằng giáo dục là phương tiện tốt nhất giúp người Tây Nguyên tự bảo vệ mình trước sự thống trị của những cộng đồng bên ngoài bao gồm người Khmer, Lào, và Việt. Giáo dục cũng được cho là cách thức hiệu quả nhất để truyền bá nền văn minh Pháp cũng như đào tạo ra đội ngũ nhân viên chuyên nghiệp, những người có thể hỗ trợ chính quyền thực dân khai thác nguồn tài nguyên thiên nhiên dồi dào, và nguồn lao động rẻ mạt một cách hiệu quả nhất. Để "Pháp hóa" hệ thống giáo dục Đông Dương, chính quyền liên bang đã tiến hành hai cuộc cải cách trong những năm 1906 và $1917^{26}$. Theo đó, một số trường tiểu học như Pháp-Ê Đê, Pháp-Ba $\mathrm{Na}$, và Pháp-Việt đã được mở tại Pleiku, Buôn Mê Thuột, và Đà Lạt. Những ngôi trường này bắt đầu tuyển sinh từ năm học 1917. Sáu năm sau, nhờ tác động tích cực từ các chính sách dân tộc của Pierre Pasquier, chương trình giáo dục tiểu học được kéo dài đến sáu năm thay

\footnotetext{
${ }^{25}$ Đối với hệ thống tư pháp ở Nam Kỳ, ngày 25 tháng 07 năm 1864, Thống đốc Nam Kỳ đã ban hành sắc lệnh đầu tiên về việc tổ chức hai loại tòa án tư pháp. Theo sắc lệnh này, tòa án Pháp đã xét xử người Pháp và những người châu Âu phạm tội, sử dụng luật pháp của nước Pháp, trong khi tòa án Nam triều xét xử người bản địa và tội phạm châu Á cư trú tại Nam Kỳ, sử dụng luật An Nam (Bộ luật Gia Long). Đến ngày 25 tháng 05 năm 1881, Tổng thống Pháp quyết định bãi bỏ tòa án Nam triều tại Nam Kỳ, giao cho tòa án Pháp ở các quận quyền xét xử người bản xứ phạm tội, trên cơ sở có tham khảo các điều khoản của luật An Nam (Dương, 2001, tr. 40-41).

${ }^{26}$ Trước đây, hệ thống giáo dục ở Tây Nguyên khá đơn giản. Trường tiểu học đầu tiên được mở ra tại Kon Tum bởi Cha Vialleton vào năm 1892. Tuy nhiên, trong những năm đầu, số lượng học sinh theo học tại trường này rất khiêm tốn. Phải rất lâu sau đó sau đó,vào năm 1908, ngôi trường tiểu học thứ hai dành cho người Thượng được đặt theo tên của Giám mục Cuénot mới được thành lập (Hồng, Cadière, \& Nguyễn, 1944; Nguyễn, 1959; Giáo phận Kon Tum, 2011).
} 
vì ba năm như trước đó. Tính đến năm học 1929-1930, có khoảng 229 học sinh dân tộc Jarai, $\mathrm{Ba} \mathrm{Na}$, Sédang, và Ê Đê đang học tập trong các trường học Pháp-Bản xứ (Phan, 2008, tr. 20).

Bước vào thập niên 1930, để giảm bớt gánh nặng khủng hoảng kinh tế thế giới, chính quyền thực dân cũng như giới chủ đồn điền đã gia tăng nhiều hình thức bóc lột và áp bức ở Đông Dương. Các sắc thuế và lao động cưỡng bức vốn đã nặng nề nay càng quá sức chịu đựng của người dân. Số giờ làm việc trung bình hàng ngày của công nhân đồn điền kéo dài đến mười sáu tiếng, trong khi tiền lương của họ bị cắt giảm đáng kể; Các trí thức và công chức bản địa bị coi thường và ngược đãi (Đinh \& ctg., 2000, tr. $221)$; Sinh viên, học sinh tốt nghiệp đối mặt với nguy cơ thất nghiệp ngày càng cao... Trong bối cảnh đó, sự trỗi dậy của các phong trào dân tộc ở Việt Nam, đặc biệt là sự thành lập và lớn mạnh không ngừng của Đảng Cộng sản Đông Dương đã làm suy yếu nghiêm trọng ảnh hưởng của thực dân Pháp ở Tây Nguyên. Ở nhiều vùng dân tộc thiểu số, các nhà cách mạng đã tịch thu điền sản của giới thực dân và tư sản mại bản để phân phát cho những người lao động nghèo khổ. Cũng cần phải nói thêm rằng, ngoại trừ những thủ lĩnh địa phương nhận được nhiều lợi ích từ người Pháp, người Thượng nói chung không sã̃n sàng hợp tác với chính quyền thực dân do họ không muốn bị phụ thuộc và lợi dụng (Hickey, 1982, tr. 325; Lacouture, 1968, tr. 48-50).

Trong các cộng đồng người thiểu số ở Tây Nguyên, Ê Đê là một nhóm đông đảo và nhận được sự ủng hộ nhiệt tình nhất từ người Pháp. Tộc người này, do đó, cũng được xem là một trong những nhóm thiểu số ưu tú nhất. Người Jarai và Sédang mặc dù cũng đông đúc và mạnh mẽ nhưng không được chính quyền thuộc địa ban cho những đặc quyền, vì các nhóm này hay can dự vào các cuộc nổi dậy chống lại sự xâm nhập và cai trị của các nhà thực dân. Cho dù nắm giữ những địa vị khác nhau trong mối quan tâm của các người Pháp, ba cộng đồng lớn này vẫn là đối tượng chính trong chính sách dân tộc của chính quyền thuộc địa trên vùng đất Tây Nguyên. Những thanh niên ưu tú người Ê Đê, Jarai, và Sédang đều được tuyển dụng vào các khóa đào tạo văn hóa, y tế, và quân sự để phục vụ với vai trò trung gian giữa chính quyền thực dân và cộng đồng người Thượng. Người Pháp cũng tiêm nhiễm vào đầu óc họ thái độ nghi ngờ, hận thù, và thậm chí khi cần thiết thì chiến đấu chống lại người Kinh. Mối quan hệ giữa người Kinh và cộng đồng các dân tộc Tây Nguyên trong thời kỳ này đã trở nên căng thẳng, đúng như mong đợi của người Pháp.

Năm 1932, tiểu đoàn lính chính quy người Thượng đầu tiên (le Bataillon des Tirailleurs Montagnards du Sud Annam) được thành lập. Tiểu đoàn này bao gồm một đại đội Ê Đê đóng tại Buôn Mê Thuột, một đại đội Ê Đê đóng tại Buôn Djen Drom, một đại đội Jarai đóng quân ở Pleiku, và một đại đội Sédang đóng tại Kon Tum. Các đơn vị chính quy này sẽ chịu trách nhiệm hỗ trợ các sĩ quan Pháp huấn luyện các binh lính mới được tuyển dụng. Từ 1933 đến 1942, năm tiểu đoàn chính quy khác với 2,172 binh lính thuộc tất cả các nhóm người Thượng tiếp tục được lập ra để phục vụ chính quyền thực dân trong các chiến dịch bình định Tây Nguyên (Nguyen, 2019, tr. 103).

Để đàn áp các phong trào biểu tình đã nổ ra ở miền Bắc Việt Nam trong giai đoạn 1930-1931, chính quyền thuộc địa đã ra lệnh cho quân đội bắn vào những đoàn 
người biểu tình làm hàng trăm người chết và bị thương. Kết thúc các cuộc đàn áp trong cao trào cách mạng 1930-1931, có đến mười nghìn người chết và năm mươi nghìn người khác bị tù đày (Hickey, 1982, tr. 359). Năm 1932, có hơn mười nghìn tù nhân chính trị bị giam giữ trong các nhà tù của Pháp trên khắp Việt Nam, trong đó, nhiều điểm giữ được đặt tại khu vực Trường Sơn-Tây Nguyên như Đắk Tô, Đắk Pék (Kon Tum), Lao Bảo (Quảng Trị), Buôn Mê Thuột... Cũng trong giai đoạn này, một tiểu đoàn gồm các binh sĩ người Thượng với trang bị súng trường cũng được tổ chức tại Buôn Mê Thuột (Hickey, 1982, tr. 360).

Từ năm 1940, tình hình trở nên khó khăn hơn với người Pháp khi quân đội Nhật nhảy vào Đông Dương. Với mục đích duy trì quyền lợi thực dân tại bán đảo này, chính phủ Vichy đã ký với Nhật "Hiệp uoớc phòng thủ chung Đông Duoong" (Protocole concernant la Défense encommun de l'Indochine Francaise) vào ngày 29 tháng 07 năm 1941. Theo đó, quân đội Nhật được tự do đi lại trên toàn cõi Đông Dương và không hạn chế về số lượng. Hiệp ước này, sau đó, xác định quan hệ Pháp-Nhật đối với bán đảo Đông Dương cho đến khi bị Nhật Bản hủy bỏ bằng cuộc đảo chính quân sự vào ngày 09 tháng 3 năm 1945 (Dương, 2002, tr. 335; Marr, 1997, tr. 28; Salemink, 2002, tr. 6). Sau đảo chính, quân đội Nhật trực tiếp kiểm soát toàn bộ lực lượng binh lính người Thượng do Pháp trang bị và huấn luyện đang đồn trú ở Tây Nguyên, đồng thời trưng dụng toàn bộ hệ thống giao thông ở đây vào mục đích quân sự. Người Nhật cũng trang bị cho một số cư dân Thượng để họ dẫn đường cho lực lượng vũ trang Nhật di chuyển trong những khu rừng nhiệt đới rậm rạp. Khẩu hiệu "Châu Á của người châu Á" đã được một số trí thức thiểu số hưởng ứng, cho đến khi Nhật Hoàng tuyên bố đầu hàng vô điều kiện quân Đồng minh vào giữa tháng 8 năm 1945. Cũng sau cuộc đảo chính, phần lớn chính trị phạm người Kinh bị Pháp giam giữ đã được người Nhật phóng thích. Trong số đó, nhiều cán bộ Việt Minh ở lại Tây Nguyên để vận động trí thức và binh lính người Thượng tham gia Việt Minh chống Pháp. Với chủ trương đoàn kết và bình đẳng giữa các tộc người, phong trào kháng chiến do Việt Minh dẫn dắt đã thu hút sự tham gia nhiệt tình của người Tây Nguyên, đặc biệt là giới tinh hoa người Ê Đê và Jarai. Sau khi Nhật đầu hàng quân đội Đồng minh, nhiều trí thức và binh lính người Thượng đã đứng ra kêu gọi đồng bào các dân tộc thiểu số chiếm đóng các trụ sở hành chính và quân sự của Pháp (do quân đội Nhật để lại) và tham gia các ủy ban hành chính lâm thời.

\section{KẾT LUẬN}

Từ thế kỷ XVII, rất lâu trước khi liên quân Pháp-Tây Ban Nha chính thức nổ súng xâm lược Việt Nam vào ngày 01 tháng 9 năm 1958, các nhà truyền giáo phương Tây đã biết đến các nhóm người thiểu số ở Tây Nguyên. Cùng với các giáo sĩ dòng Tên, những khám phá của các nhà thám hiểm người Pháp dần hé lộ rất nhiều bí ẩn ở vùng núi phía nam Đông Dương. Những báo cáo của các nhà truyền giáo và thám hiểm được sử dụng làm căn cứ quan trọng giúp chính phủ Pháp hoạch định các chiến lược xâm chiếm và sau đó là chính sách cai trị ở Tây Nguyên.

Dù được che đậy bằng những khẩu hiệu hoa mỹ như "Khai hóa văn minh", "Đất Tây Nguyên của người Tây Nguyên", và "Quy chế đặc thù", mục đích sau cùng của thực dân Pháp khi xâm lược và cai trị Tây Nguyên cũng như ở các "kỳ" khác của Việt 
Nam, Lào, và Campuchia là vơ vét nguồn tài nguyên phong phú và nhân công rẻ mạt; Mở rộng thị trường tiêu thụ hàng hóa cho giới tư bản Pháp; Mở rộng ảnh hưởng của văn minh Pháp ở Đông Dương và Viễn Đông.

Có một thực tế là các quan chức người Pháp ở Tây Nguyên thường tỏ ra khá thành thạo trong xử lý công việc hành chính giữa chính quyền thuộc địa và cộng đồng người Thượng. Sự khôn ngoan trong chính sách dân tộc, đặc biệt là các chính sách về văn hóa đã khiến cho nhiều tù trưởng địa phương ngộ nhận và đặt niềm tin vào "thiện chí” của các nhà cai trị. Một số tù trưởng sau đó đã tham gia bộ máy công chức trong hệ thống chính quyền cơ sở, giúp kẻ thù cai trị và bóc lột chính đồng bào của mình. Về phương diện này, có thể nói phương thức "Dùng người bản xứ cai trị người bản xứ" đã được thực dân Pháp áp dụng tương đối hiệu quả ở Tây Nguyên. Sau khi được thành lập, tên gọi và địa giới hành chính của các tỉnh, cũng như hệ thống đô thị trung tâm tỉnh lỵ ở Tây Nguyên đã được điều chỉnh nhiều lần trong giai đoạn 1905-1941. Sự chia tách, điều chỉnh các đơn vị hành chính ở vùng người Thượng về bản chất vẫn là chính sách "Chia để trị” truyền thống của chủ nghĩa thực dân.

Dù mục tiêu sau cùng là phát huy cao nhất hiệu quả cai trị của chính quyền thực dân, chính sách dân tộc của người Pháp ở Tây Nguyên cũng mang lại một số tác động tích cực nhất định trong đời sống kinh tế-xã hội và văn hóa của cộng đồng các dân tộc thiểu số ở Tây Nguyên. Sự sắp xếp và điều chỉnh các đơn vị hành chính cùng với mạng lưới giao thông hiện đại được mở mang dưới thời thuộc địa đã góp phần quan trọng trong việc định hình các đơn vị và trung tâm hành chính ở Tây Nguyên hiện nay. Sự am tường về ngôn ngữ và văn hóa bản xứ cùng với niềm đam mê khám phá đã giúp các nhà dân tộc học người Pháp (trong đó có một số vốn là quan chức hành chính và sĩ quan quân đội) hoàn thành nhiều công trình khoa học có giá trị về cộng đồng người Thượng. Những điều chỉnh về chính sách văn hóa dưới thời Toàn quyền Pasquier và "quy chế đặc thù” thời kỳ Hoàng triều Cương thổ đã giúp khôi phục và lưu giữ một số bộ luật tục truyền thống cũng như các di sản văn hóa và ngôn ngữ khác của các sắc tộc thiểu số; Một số hủ tục như mê tín dị đoan cũng từng bước bị bài trừ; Các phương pháp canh tác tiến bộ được khuyến khích...

Có thể nói, giải thực dân hóa là một xu hướng tất yếu trong diễn trình lịch sử của các quốc gia thuộc địa và phụ thuộc sau Chiến tranh Thế giới thứ II. Bất chấp những nỗ lực cuối cùng trong việc duy trì quyền lực thực dân ở Tây Nguyên, cho đến khi thực dân Pháp buộc phải rút khỏi Việt Nam sau Hiệp định Giơ-ne-vơ, hầu hết các chính sách kinh tế-xã hội được họ triển khai ở vùng người Thượng đã không chạm tới những mục tiêu mong đợi. Như đã phân tích ở trên, sau Cách mạng tháng Tám, đa số đồng bào các dân tộc thiểu số đã lựa chọn chiến đấu dưới ngọn cờ độc lập dân tộc do Đảng và Mặt trận Việt Minh lãnh đạo. Sự đóng góp tích cực đó đã góp phần quan trọng làm nên thắng lợi của Cuộc Kháng chiến của toàn dân tộc vào năm 1954.

\section{TÀI LIỆU THAM KHẢO}

Borri, C. (2014). Xú Đàng trong năm 1621 (N. Hồng, K. X. Nguyễn, \& N. Nguyễn, Dịch). TP. Hồ Chí Minh, Việt Nam: NXB. Tổng hợp. 
Bùi, M. Đ., Trần, H. T., \& Bùi, B. L. (2006). Dân tộc Ba Na ở Việt Nam. Hà Nội, Việt Nam: NXB. Khoa học Xã hội.

Cửu, L. G., \& Toan, A. (1974). Cao nguyên miền Thượng. Được truy lục từ http://www.tusachtiengviet.com/images/file/n7rTck5c0wgQAB0k/caonguyenmi enthuong1.pdf.

Dournes, J. (2013). Po tao, một lý thuyết về quyền lực của người Gia Rai ở Đông Dương (Pötao, une théorie du pouvoir chez les Jörais indochinois) (N. Nguyên, Dịch). Hà Nội, Việt Nam: NXB. Tri thức.

Dương, K. Q. (2001). Việt Nam nhũng sụ kiện lịch sủ 1958-1918. Hà Nội, Việt Nam: NXB. Giáo dục.

Dương, T. Q. (2002). Việt Nam nhũng sụ kiện lịch sủ 1919-1945. Hà Nội, Việt Nam: NXB. Giáo dục.

Đinh, X. L., Nguyễn, V. K., \& Nguyễn, Đ. L. (2000). Đại cưong lịch sử Việt Nam. Hà Nội, Việt Nam: NXB. Giáo dục.

Đoàn, T. (1966). Việc tùng ngày 1945-1964. Sài Gòn, Việt Nam: Nam chi Tùng thư.

Giáo phận Kon Tum (2011). Mùng 100 năm thành lập trường Yao Phu Cuénot (19082008). Được truy lục từ https://gpkontum.wordpress.com/2011/02/20/ k\%E1\%BB\%B7y\%E1\%BA\%BFu-nam-thanh-yao-phu/.

Hickey, G. C. (1982). Sons of the mountains: Ethnohistory of the Vietnamese Central Highlands to 1954. Connecticut, USA: Yale University Press.

Hồ, C. M. (1946). Thu gưi Đại hội các dân tộc thiểu số miền Nam tại Plây Cu (Pleiku). Được truy lục từ: https://www.nhandan.com.vn/chinhtri/item/7033602.html.

Hồng, L., Cadière, L., \& Nguyễn, V. T. (1944). Lịch sủ Đạo Thiên Chúa ở Việt Nam. Huế, Việt Nam: Đại Việt Thiện bản.

Lacouture, J. (1968). Ho Chi Minh: A political biography. New York, USA: Random House.

Lê, Đ. C. (2006). Người thượng miền Nam Việt Nam. California, USA: NXB. Văn mới.

Lê, N. (2019). Cuộc phiêu lưu của Marie đệ nhất - Quốc vuơng xú Sedang. TP. Hồ Chí Minh, Việt Nam: NXB. Tổng hợp.

Li, T. (1998). Nguyễn Cochinchina: Southern Vietnam in the seventeenth and eighteenth centuries. Ithaca, USA: Cornell Southeast Asia Program Publications.

Maitre, H. (2008). Rìng người Thương (Les Jungles mois) (Đ. T. Lưu, Dịch). Hà Nội, Việt Nam: NXB. Tri thức.

Marr, D. G. (1997). Vietnam 1945: The quest for power. California, USA: University of California Press.

Moore, D. K. (2007). Tribal soldiers of Vietnam: The effects of unconventional warfare on tribal populations. Indiana, USA: Xlibris Corporation.

Nguyễn, H. (1959). Lịch sủ truyền giáo ở Việt Nam. Sài Gòn, Việt Nam: NXB. Hiện tại. 
Nguyen, V. B. (2019). From colonial to post-colonial rule: The transformation of rule in an important strategic area in South Vietnam. Bern, Switzerland: Peter Lang GmbH.

Nguyễn, V. K. (2000). Co cấu kinh tế xã hội Việt Nam thời thuộc địa (1858-1945). Hà Nội, Việt Nam: NXB. Đại học Quốc gia.

Paul, N. (1966). So luợc về chính sách Thương vu trong lịch sủ. Sài Gòn, Việt Nam: Văn phòng Phủ Đặc ủy Thượng vụ.

Pentagon, P. (1971a). Background to the crisis, 1940-1950. Boston, USA: Beacon Press.

Pentagon, P. (1971b). U.S. Involvement in the Franco-Viet Minh war, 1950-1954. Boston, USA: Beacon Press.

Phan, K. (1961). Việt Nam Pháp thuộc sủ 1884-1945. Sài Gòn, Việt Nam: NXB. Khai Trí.

Phan, T. B. (2008). Nhìn lại hai cuộc cải cách giáo dục (1906 và 1917) ở Việt Nam đầu thế kỷ XX. Tạp chí Nghiên cúu Lịch sủ, (5), 11-20.

Po, D. (2012). Tù FLM đến Fulro: Cuộc đấu tranh của dân tộc thiểu số miền Nam Đông Dưong 1955-1975. California, USA: IOC-Champa.

Quốc hội. (2019). Danh sách đại biểu Quốc hội Khóa I. Được truy lục từ: http://dbqh.na.gov.vn/I/Daibieu.aspx.

Quốc sử quán triều Nguyễn (2001). Khâm định Việt sử thông giám cuơng mục. Hà Nội, Việt Nam: NXB. Giáo dục.

Salemink, O. H. J. M. (2002). Vietnam: Indigenous minority groups in the Central Highlands. Retrieved from https://www.refworld.org/docid/3c6a48474.html.

Tonnesson, S. (2009). Vietnam 1946: How the war began (Vol. 3). California, USA: University of California Press.

Touneh, H. T. (1970). Phát triển xã hội Thượng trong triển vọng phát triển quốc gia (Luận văn tốt nghiệp). Trường Cao đẳng Quốc phòng Đà Lạt, Việt Nam.

Thái. P. A. (2003). Trăm núi ngàn sông. Los Angeles, USA: NXB. Đường Việt Hải ngoại.

Trung tâm Lưu trữ Quốc gia I. (2013). Tổ chức bộ máy các cơ quan trong chính quyền thuộc địa ở Việt Nam qua tài liệu và tài liệu luu trũ (1862-1945). Hà Nội, Việt Nam: NXB. Hà Nội.

Ủy Ban Dân tộc. (2012). Nghị định số 359, ngày 9-9-1946, chiểu theo Sắc lệnh số 58, ngày 3-5-1946 của Chủ tịch Chính phủ Việt Nam Dân chủ Cọng hoà. Được truy lục từ http://files.ubdt.gov.vn/ContentFolder/ubdt/source_files/2016/06/06/1351 0828_Sotaychatluong_16-06-06.pdf. 